\title{
Koreans in Japan: Processes of Community Building in Marginal Places in Kyoto
}

\author{
Nataša VISOČNIK*
}

\begin{abstract}
The article mostly deals with an area on the southeast of Kyoto, which is known to be settled also by the Korean minority. The research based on a few short fieldworks focuses on their struggle to gain access to the resources through the process of community building (machizukuri). The process of machizukuri began under the liberation movement of another marginalized group known as burakumin, who live in the neighbourhood area. The research also looks for the relationship between these two discriminated groups. This article thus challenges the idea that the involvement in the process of community building of one group serves as a know-how for other marginal communities for collaborations with cities and local self-governing establishments.
\end{abstract}

Keywords: zainichi Koreans, machizukuri, marginality, burakumin, local self-government

\section{Izvleček}

Članek predvsem obravnava z območjem na jugovzhodu Kjota, kjer je znano, da živi tudi korejska manjšina. Raziskava, ki temelji na nekaj kratkih terenskih raziskavah se osredotoča na njihov boj do dostopa virov skozi proces oblikovanja skupnosti (machizukuri). Proces machizukuri se je začel v okviru osvobodilnih gibanj druge marginalizirane skupine znane kot burakumin, ki živi v sosednjem območju. Raziskava si tudi ogleda odnose med tema dvema diskriminiranima skupnostma. Tako članek tudi izziva ideje, da lahko vključevanje v proces oblikovanja skupnosti ene skupine služi kot izkušnja za druge marginalne skupnosti v sodelovanju z mesti in lokalnimi samoupravami.

Ključne besede: zainichi Korejci, machizukuri, marginalnost, burakumin, lokalne samouprave

\footnotetext{
* Nataša Visočnik, PhD, Assistant Professor, Department of Asian and African Studies, Faculty of Arts, University of Ljubljana, Slovenia. natasa.visocnik@ff.uni-lj.si
} 


\section{Introduction}

In recent years local citizens' movements have spread rapidly throughout Japan. There is considerable evidence of high levels of motivation and enthusiasm among Japanese people for efforts to make more liveable places, as demonstrated by the spread of machizukuri across the country during the 1990s. Created with the aim of improving the quality of the local environment, and of environmental management processes, such activities are widely referred to as machizukuri, and represent an important development in local politics and urban management in Japan. Thousands of machizukuri (also called "community building") processes have been established nationwide, in an enormous outpouring of local energy into attempts to achieve more bottom-up input into local place management in which local citizens play an active role in environmental improvement and management processes.

This article looks into these processes of community building from a perspective of marginal group living in south-east of Kyoto. Marginalised communities in Japan often live in particular parts of big cities, usually on their outskirts, where members of oppressed ethnic groups, the impoverished or lower castes live. One of such places is the districts called Higashi Kujo in Minami-ku at the south-east part of Kyoto city. The research based on a fieldwork in this area focuses especially on one main group living there; the Korean minority (zainichi Kankokujin or resident Koreans).

The process of machizukuri began under the liberation movement of another marginalized group known as burakumin, who live in the neighbourhood area (Sūjin area in Shimogyō-ku). The research also shortly compares the struggle of the Korean minority and burakumin minority groups and particularly looks for the relationship between the two discriminated groups. In the case of burakumin, the negative consequences of marginality served as a starting point for innovation and potentials, expressed in the community building very successfully.

In this way, article also challenges the idea that the involvement in the process of community building of one group serves as a know-how for other marginal communities for collaborations with cities and local self-governing establishments.

After a brief introduction of the place and the term "marginality", the article outlines the origins of the social phenomenon zainichi Korean discrimination. Then it considers in more detail the developments and modernization processes 
within the life in buraku, and discusses the important role of machizukuri in the liberation movement in the course of the $20^{\text {th }}$ and $21^{\text {st }}$ century. Buraku ("hamlet") or tokushu buraku ("special hamlet") are home to people with criminal backgrounds, criminal ancestors, people of foreign ancestry (especially Korean), people living in poverty or/and having an unclean occupation (or an ancestor with one). The oldest buraku neighbourhoods are believed to be in Kyoto, the ancient capital, and go back a millennium, in its history.

The question is why do modernity symbolized by the dismantling of the outcast status groups, the legislation of "equality", and progress towards a capitalist economy faile to do away with feudal prejudices and still pushes those people to the margins of the mainstream society even nowadays.

\section{Marginal Place}

A marginal place of a big city was historically a place where coexistence of and confrontation between the impoverished working class, or minorities on one side, and the majority, the capital on the other side were generated. Two of such marginal spaces in Kyoto are Higashi Kujō Minami-ku${ }^{1}$ where Korean minority lives, and Süjin in Shimogyō-ku where burakumin live on the south-east part of the city. These areas served as a border line of the city for hundreds of years and these liminal spaces were settled by various kinds of people.

Mizuuchi $(2002,13)$ argues that this kind of confrontation caused urban poverty in the context of industrial capitalism, which represented economic poverty and feudal and classist marginality, and poverty determined by social status and ethnicity. In the Meiji Restoration period (1868-1912), urban space experienced a drastic transformation along with revolutionary changes in spatial and social structures. The living space shared by factory labourers, an increasing

\footnotetext{
${ }^{1}$ The place Minami or South Ward (南区 Minami-ku) is one of the eleven wards in the city of Kyoto in Kyoto Prefecture. As of April 2008, the ward has had an estimated population of 98,320 people. It is roughly bound to the east by the Kamogawa (Kamo River), to the west by the Katsuragawa (although it extends across the river in some places), to the north by Hachijo Street and the JR Kyōto line (leading into Kyoto station), and to the south by the Meishin Expressway (although it extends across the expressway in some places). (Minami ku)

${ }^{2}$ Shimogyō-ku has a population of 75,748 and an area of $6.82 \mathrm{~km}^{2}$. Three rivers, Horikawa, Kamogawa and Takasegawa, are in the ward. Kyoto Tower and Kyoto Station are major landmarks in Shimogyō-ku. Shijō Street on the northern edge of the area, especially around the Shijō Kawaramachi intersection, is the busiest shopping district in the city. Kyoto Station has an extensive shopping centre, including a department store in the station building, and the underground Porta mall. (Shimogyō-ku)
} 
number of workers of urban miscellaneous jobs, and manufacturers unable to adjust to the progress of technology became the "slum" area, where the urban poverty previously hidden behind the feudal class system became spatially visible. Regulations covering construction, hygiene and lodgings, combined with land price and rent increases related to the emergence of an urban middle class, forced many poorer people to move from relatively central metropolitan areas into specific outlying districts. Since the Taishō period (1912-1926), people from the colonized Korea migrated to urban areas next to minor factories, neighbouring these ghettos and cheap inns' quarters, and giving them an additional characteristic of spatial division among ethnic groups.

Today in these two areas, especially in Minami-ku live more people from the working class than in any other Kyoto districts; many of them came from rural areas in search of employment, in addition to those who have emigrated for a variety of reasons from other regions. Besides restaurants and clubs, portions of the land near the Kamo River are lined with factories and industrial buildings. Residential areas include both standard houses and apartments, and occasional government-subsidized housing projects in public housing, where people with disabilities are placed as well. Because of the big zainichi Korean community Higashi Kujō is sometimes called "Kyoto's international town". The terms buraku (hamlet), tokushu buraku (special hamlet) or dōwa chiku (assimilation districts) are used to describe the place Sūjin where burakumin live just next to Higashi Kujō.

The people living in this area are all marginalised, though for different reasons. The marginalised people might be socially, economically, politically and legally ignored, excluded or neglected, and are therefore vulnerable to livelihood change. According to Gurung and Kollmair $(2005,10)$ marginality is primarily defined and described by two major conceptual frameworks, the societal one and the spatial one, which are both possible to find in these two cases. The societal framework focuses on human dimensions such as demography, religion, culture, social, economics and politics in connection with access to resources by individuals and groups. This was how both the burakumin as native Japanese but a caste and zainichi Koreans as a foreign ethnicity were marginalized in one sense. As both groups live at the edge of the city, they are also spatially marginalized. The explanation of the spatial dimension of marginality is primarily based on physical location and distance from centres of development, lying at the edge and poorly 
integrated into the system (Gurung and Kollmair 2005, 10), as we can see in Kyoto city.

\section{Zainichi Koreans in Japan}

The notion of ethnic Koreans residing in Japan challenges the assumption that Japan is "homogeneous" (see Hicks 1997; Ryang 2005) and also raises questions about what it means to be "Korean" or "Japanese". Koreans constitute the largest "foreign" community permanently residing in Japan. ${ }^{3}$ Despite their similarities in physical appearance and considerable acculturation to mainstream Japanese society, Koreans in Japan have been discriminated against by both the Japanese state and Japanese society. They continue to face and respond to numerous forms of discrimination, human rights violations and social injustice, as well as intracommunal political diversity, which is relevant to others' experiences in the West and beyond. ${ }^{4}$

Japan colonized Korea for three and a half decades from 1910 to 1945, incorporating Koreans and other Asians within its expanding empire. Its empirebuilding coincided with its attempts at modern nation-building after the 1868 restoration of imperial order under Emperor Meiji. The Japanese in Korea, Taiwan, Okinawa, Manchuria and elsewhere sought simultaneously to establish their own privileged position and to assimilate the colonized people though the imposition of the Japanese language and education system (Ryang 2005, 2). At the beginning they were given Japanese citizenship, which however did not protect them from discrimination, although the government tried to infuse the heterogeneous population with a sense of homogeneity and community (Weiner 2009, 1). In 1947 their citizenship was revoked; they were classified as aliens and given foreigner's passports. The Koreans were forced to work in mines and munitions factories (Fukuoka and Tsujiyama 1991, 5) and the assimilation politics at that time extended to every aspect of life-political, religious and cultural. From 1939 on the sōshikaimei ${ }^{5}$ policy forced many Koreans to adopt Japanese-style names and abandon their Korean names (Ryang 2005, 2; see also Fukuoka 2000, 6). Although according to the Naturalization Laws Koreans are no longer required to adopt

\footnotetext{
${ }^{3}$ According to statistics from the Ministry of Justice, there were 565,989 Koreans in Japan in 2010. This figure does not include those who have adopted Japanese citizenship, which might be around 284,840 according to the figures from 2005 . Added to this number should also be long-term visitors $(82,666)$, Korean students in Japan $(18,208)$, who make up 950,703 in total. (Ministry of Justice 2010)

${ }^{4}$ For an in-depth account about the Korean minority living in Japan, see Visočnik (2013).

${ }^{5}$ The term literary means "create a surname and change one's forename" (Fukuoka 2000, 6).
} 
Japanese-style names, there is informal pressure for them to do so as we can learn from many personal stories. This stems from the fact that, as Hicks $(1997,86)$ has argued, in Japanese thinking, race and ethnicity are not separated. They are called zainich $i^{6}$ Koreans, but the term "Korean-Japanese" is also in use, although is not officially recognized and has two essential characteristics, describing people who are of Korean descent and live in Japan.

Working low-paid jobs and settling at the edge of cities, they quickly became defined as "impure". Although no longer officially recognized after 1871, their idea of "dirty people" based on occupation such as the burakumin ${ }^{8}$ in feudal Japan and baekjeong in feudal Korea was to supply motivation for all members of Japanese society to maintain their own "purity" and avoid "dirt". 9 Thus Koreans were cast in a similar role as "dirty people"—chōsenjin-burakumin in Japan.

As eta people were already residing in Tokujō, Koreans came to Kyōto in the 1920s, at the time of large-scale construction of the Tokaido Line of Railways (Maekawa 1974, 39), the Higashiyama tunnel construction, river wall construction of Kamogawa and widening construction of Kujō Street, and the development of the Yūzen dyeing factory, whenever the need for workers was big. The Korean population of Tokujo increased significantly in the time of the large black market that appeared in the region (today's Kyoto Station). The market especially flourished after the end of the war, when a lot of Koreans planned to return home

\footnotetext{
${ }^{6}$ The term zainichi emphasizes place of residence rather than bloodline. Since the late 1970 s, the younger generation has used the term to emphasize their different approach to living in Japan to that of the first generation zainichi. This term also avoids the inclusion of nationality as a defining element in identifying this community (Chapman 2008, 4-5; Inadsugi 2002, 559-62).

7 The term "Korean-Japanese" does not exist in order to keep the myth of racial homogeneity alive and it is also a contradiction in terms, since a person can be either one or the other, but not both. This is hard for many Koreans to accept since they feel that retaining their cultural identity is a fundamental right. In relation to this, even today Japan refuses to allow dual nationality for its citizens.

${ }^{8}$ Burakumin were discriminated because of their occupation or a specific location of their living since ancient times. Discrimination of the burakumin is religiously-sanctioned class discrimination. A key concept in understanding any such form of discrimination is that of "defilement". Something is "defiled" (kegare) when it is out of its "proper" place in society. (Mist 2012, 6; Boyle 1; see also Buraku Liberation League) Much like day labourers in modern Japan, those who were marginalized ended up doing the "3-D" jobs (dirty, difficult and dangerous) that society needed done but which nobody wanted to do. (See more in Visočnik 2014)

${ }^{9}$ This dirtiness is usually associated with the fact that Koreans bred pigs, as pork was an important element of the Korean diet. It also associated with smell, because Korean people in the past were considered as "bad smelling", as the interviewees would say. Garlic, which was a very important ingredient in Korean cuisine (like kimchi, キムチ) and which Japanese people did not use at all in their cuisine, also had a strong smell. Koreans were also excluded from the general housing market and forced to live in tenements and flop houses with poor sanitation and basic health care problems.
} 
and sold rice ("black-market rice") at the train station before leaving Kyoto. Those who stayed worked in the field spreading to the south. They also collected waste paper and scrap iron, old clothes and sold them in their shops. At that time, the population of Tokujo was about 30,000 people and among them, 10,000 were Koreans. They lived in a poor living environment in the so-called "illegal housing"; there were also lots of fires, where many people lost their lives. ${ }^{10}$

When Koreans immigrated to Japan, they joined the outcasts at the bottom of the industrial reserve army. When workers' movements began, the mechanisms for ideological discrimination and ideological suppression developed. To combat the rising working-class consciousness after the Rice Riots of 1918, the Public Security Law was passed in 1925 to provide the legal framework for the suppression of "communistic" ideas. In the Marxist view then, the structure of prewar Japanese capitalism supported status discrimination in both its objective and subjective aspects. In the post-war period, with the Fascist movement defeated and discredited, the Japanese society underwent firstly a revolutionary and then a counterrevolutionary development. The key forces underlying change in the revolutionary phase were pressures from below, from the progressive social forces of the Japanese society, and the American Occupation operating under the principles of the Potsdam Declaration. The revolutionary period was marked by various reforms. (Neary 2009)

Ruyle $(1979,63)$ states that their racial discrimination had its origin in the conquest of Korea and the promulgation by the ruling class of the idea that the Japanese were a superior race. The cultural identity and citizenship issues have been a major problem between the Koreans and the Japanese government, which still remains to be solved today. The formation and transformation of ethnic identity and cultural diversity are concerns Koreans in Japan share with many other minority groups in the contemporary society. Japan's national identity is produced and reproduced by discursive strategies rather than by reality itself. (see also Visočnik 2013, 114-6) Although zainichi Koreans live in buraku together with burakumin they are treated in a different way from burakumin. According to

\footnotetext{
${ }^{10}$ There is another place near Kyoto, called Utoro, in Kyoto Uji Iseda town, where one community of zainichi Koreans lives. They moved there during the war to work in a military airfield the Japanese tried to build. In the mid-1980s, Nissan Motor Co., a successor to the war-time company, contrived to evict them from their homes by selling all of the village land. With much struggle in US courts and by going public, they won support for their cause, and awareness about the wartime compensation issues. The town is also connected with Tokujo, as they have performed in the Madang festival in Tokujo.
} 
McCormack $(201376,77)$, they are called new comers or commoners and are like poor labourers, orphans and discharged criminals. In the past the differences were even greater, but today government's actions to improve the living conditions in marginal areas are getting closer and similar to the ones of burakumin's.

Koreans form the largest ethnic group in contemporary Japan. They are also a diverse group. The most important boundary lies between "newcomers", who are a "voluntary minority", and "old-timers", who are an "involuntary minority". The newcomers were born and mostly educated in South Korea, and came to Japan to obtain better economic benefits. They do not intend to reside in Japan permanently. Many of them are illegal workers, estimated to number 320,000. Newcomers are younger, more self-confident, and more aggressive; they are more driven to succeed, compared with the old-timers. (Okano 1997, 526-7)

Among the long-term resident Koreans, further divisions exist. The majority are permanent residents of Japan, representing 688,144 of a total 1.28 million registered foreign residents. Others have taken up Japanese citizenship: The number of ex-Koreans who were naturalized in the period 1952-90 is estimated to be 155,547 . Differences are observed in terms of generation, affiliation with North and South Korean organizations, regions of residence, and social class. (Okano 1997, 527) Long-term Korean residents in Japan are an involuntary minority group. The existence of the Koreans in contemporary Japan is a direct result of Japan's colonization of the Korean peninsula from 1910 to 1945.

The original Koreans fled to Japanese cities in pursuit of employment after being dispossessed of their farming lands by the Japanese colonial authorities, or from 1937 to 1945, being shipped to Japan as forced labour to fill an acute shortage of workers in the war economy. The Korean population in Japan at the end of the war was almost 2,3 million, about three quarters of whom returned to Korea within a year after the end of the war. Those who stayed on longer in Japan soon faced the division of Korea in 1948 and the outbreak of the Korean War, which made their repatriation difficult. Under Japanese colonization, Koreans were Japanese subjects, but in 1952 when Japan regained sovereignty, Koreans living in Japan suddenly and unilaterally became foreign nationals.

There remains a legacy of the colonial period when the dominant Japanese "defined" Koreans as an inferior and second-class group of people and deliberately discouraged the maintenance of their language and ethnic culture. Koreans, as well as Japanese, are said to have internalized this definition: they hold a negative 
identity of themselves and their culture. Had a different definition been applied to Koreans as an ethnic group, they might well have experienced different treatment.1 While facing symbolic prejudice and discrimination in interpersonal relations in common with the other three involuntary minority groups (the Ainu, the Okinawans, and the buraku), most Koreans face the added disadvantage of not possessing Japanese citizenship, such as limited access to government employment. (Okano 1997, 527-8; Kim D. 2002, 5)

It is public knowledge that Koreans face barriers in the employment market, although its extent is difficult to quantify. Koreans have been denied access to employment in public service, which requires that applicants be Japanese nationals. Osaka prefecture eliminated its restrictions in respect of public school teaching in 1973, a decision followed by several other local governments in the 1980s. The elite government law school from which all of Japan's aspiring lawyers must graduate was closed to foreign nationals until a young Korean resident won his case in the Supreme Court in 1977. In the 1970s, several court cases against prestigious employers who refused Korean applicants on the basis of foreign nationality were resolved in favour of the plaintiffs. In spite of improvements brought about by these cases, Koreans have yet to achieve equal access to the employment market. Disillusion is experienced by all young Koreans seeking a place in the workforce but is felt more keenly by better-educated Koreans who have formed high expectations for their adult life. (Okano 1997, 529)

The term Japan-Residing Koreans refers to the permanent ethnic Korean residents of Japan. Technically, it designates only those "Korean immigrants" who have lived in Japan since prior to August 15, 1945, and applied for the permanent residency within 2 years after the end of the War, as well as their direct descendants. They constitute the largest ethnic minority group in Japan. According to the Korean Residents Union in Japan, the population of Japan-Residing Koreans as of the year 2005 was approximately 600,000. As the term (i.e., Japan-Residing Koreans) suggests, they are not Japanese in any legal sense. They used to be required by law to register their fingerprint; this infamous "fingerprint law" was abolished in January, 1993. Nonetheless, all Japan-Residing Koreans have Korean nationality and they still are required to carry the Alien Registration Certificate while they are in Japan (Fukuoka 2000, 5; Ministry of Justice 2010).

Also notable about Japan-Residing Koreans' societal positionality is that the group designated by this term does not include the Koreans who have been 
naturalized because such individuals have Japanese nationality. (Matsunaga and Torigoe 2007, 350)

\section{Building a Place to Live - machizukuri}

Since the collapse of the bubble economy in the early 1990s, machizukuri groups and processes have spread widely throughout Japan. (Sorensen and Funck 2007) Shortly after the Great Hanshin Earthquake the government saw itself unable to cope with the crisis as efficiently as the local and regional Non-Profit (NPO) and thus volunteer organisations engaged in machizukuri. This was the beginning of a more serious consideration of the social aspects of community building on the part of the Liberal Democratic Party (LDP), which adopted machizukuri ${ }^{11}$ as a part of its platform.

There were several factors that contributed to the boom in suburban housing at this time. First, as mentioned above, the rapid growth of the economy during the first two decades of the $20^{\text {th }}$ century had led to a swelling of the ranks of the working class crowded into existing urban areas and new industrial districts adjacent to them. This caused both upward pressure on rents and a declining quality of life in large cities. Second was the rapid expansion of white collar middle class salaried workers who filled management positions in the emerging industrial sector and staffed the growing government bureaucracy. This new class could afford a daily train fare which the working classes could not, and provided a growing market for suburban homes beyond the urban fringe industrial belts out in the open countryside where land was cheaper and the environment better. While the old urban middle class tended to hold on to their city centre shop-houses, these were frequently devoted primarily to the business, and the primary residence shifted to the new suburbs. Third was the technological development in the railway industry where electrification was proceeding rapidly, especially in the suburban lines in the metropolitan areas, allowing a much more flexible approach to the development of new lines and stations than was the case with steam engines, which were slower to accelerate and more suited to inter-city trunk lines where the stations were spaced further. (Sorensen 2002, 140)

A fourth factor was also crucial: government regulation of the rail industry. In 1906 the state had bought out virtually the whole private railway sector (at that

\footnotetext{
${ }^{11}$ The term can be translated as "coomunity development", "neighbourhood building" or "town making".
} 
time with almost twice the length of track in service as the government-built railway system) to create a national inter-city rail system, leaving only a few lines in private hands, primarily those in the larger metropolitan areas where there had been considerable duplication. (Sorensen 2002, 140)

Activities in this process include an extremely broad range of projects, from the building of new parks and community centres, to historical preservation, to creating new housing types, to revitalization of declining shopping areas and environmental remediation projects. What is new is the increasing involvement and legitimacy of residents as volunteers in such processes, and the increasing willingness of local governments to support such voluntary activities.

The process of urbanization has been especially strong since the $1960 \mathrm{~s}$, but only since 1990s the idea of machizukuri became a leading process. It was first conceived as an ideological counterpart to conservative city planning. Local communities unified in Neighbourhood Associations (chōnaikai, jichikai, and burakukai), and some of these NAs had an essential role in liberation movements for rights of burakumin in buraku in Kyoto. (Yamamoto 2009, 38) Beside modernization and improvement of a city and living conditions with building up new houses and facilities, the resident movement in Kyoto has also a power to achieve preservation of an important heritage, such as the Bank of Yanagihara, a bank found by burakumin community in Kyoto. The Buraku liberation movement was able to exercise great political power, and large amounts of national funds were invested over a 27 -year period in the buraku as dowa assimilation projects.

First issue of the community building is creating more liveable and sustainable cities. It is widely argued that one of the great challenges of our time is to learn how to create more liveable cities, that are economically vibrant, provide high quality of life and health for their residents, and contribute to long-term environmental sustainability through reduced resource consumption and waste production. Neighbourhood-based machizukuri movements in urban Japan are an important case of attempts to move towards such goals, and should be better understood. (Sorensen and Funck 2007, 2)

A second major set of issues to which the study of machizukuri contributes is the questions of local governance, and the changing roles of and relations between central and local government, and between citizens and the state, in managing shared spaces that have been the focus of intense interest during the last decade and more. One important aspect of machizukuri is the attempt to strengthen and 
gain greater involvement of and legitimacy for local community-based organizations in managing processes of urban change. Such urban management is the responsibility of local governments, although these operate within the context of significant constraints imposed by senior governments and their own position within regional, national, and global economic systems. (Sorensen and Funck 2007, 2)

The third major set of debates is the changing conceptions of the role of civil society in governance. One of the key sites of practical attempts to create new governance practices and priorities has been at the scale of the urban neighbourhood through the machizukuri processes studied. (Sorensen and Funck 2007, 3)

Machizukuri processes are also generating a growing depth of experience and expertise in participatory environmental management. The rapid spread of such processes indicates that many people value local environmental quality enough to invest a lot of time in working together to improve it. In a context of population ageing and population decline, new place-making strategies - already emerging in the more innovative settlements - are at a premium. Population decline is already creating a new dynamics in local governance in Japan, in which the creation of highly liveable places, with a welcoming atmosphere, quality services, and high amenity physical environments may become a significant priority. (Sorensen 2002)

The bubble economy gentrified inner cities, whose land represented an object of investment and speculation. Apartment and office buildings were built, changing the urban landscape previously dominated by gray and flat houses (Mizuuchi 2002, 28). Furthermore, dōwa districts have moved into the public limelight, having developed pioneering projects and welfare for the aged and handicapped as an experimental example of urban regeneration projects.

\section{Koreans in Kyoto}

However, that was the case with the burakumin, which was different from the situation with the zainichi Koreans living on the margins of cities. In Osaka, for example, the ethnic enclave was reproduced in Ikuno-ward, which was dominated by zainichi people; Korean residents in Japan. The wooden tenement housing for working-class people was there, but there was also a number of public housing to which zainichi people had no access. (Mizuuchi 2002, 27) The situation in Kyoto 
was similar, with small private businesses, but resident buildings were not originally constructed for them.

While the first-generation of zainichi people tried to develop their own businesses without demanding rights as Japanese citizens, the second and third generation peoples insisted on their fundamental rights as permanent residents. Their movement addressed the severe reality regarding the violation of rights of foreigners who were permanent residents of Japan, and demanded institutional change. They refused to be fingerprinted not necessarily because of the ideological antagonism between South and North Korea, but because their demands derived from their daily lives. In the 1990s, zainichi people finally won rights for access to public housing and pension. Moreover, they were now entitled to become government employees. (see Weiner 2009; Ryang 2005)

In 1997 Special Measures Law was extended: benefits for other disadvantaged groups who were welcome to live in buraku in the spirit of building a diverse and richer community. That meant that also other ethnic groups could move in. But that was not the case in Kyoto, where two groups were not really cooperating well at that time.

The second attempt in Kyoto to bring together different groups was the programme of Kyoto city "Outline of the Master Plan of Kyoto City (2001-2010)", which also emphasized the city where all people could live without discrimination and violation of human and civil rights, as we can read on the website of Kyoto's city municipal (Kyoto City 2010).

Though the connection between the buraku area and zainichi area has never really become stronger, there were also other benefits that came from these programmes, especially in last few years for Koreans. A new home for elderly was built in Higashi Kujō, there were many new apartment homes built, parks were renewed and new community centres were built. What is really interested is that the idea of diverse community life is much more present in the Korean community, where we can find people from other ethnic backgrounds moving into new apartment homes than in the buraku area.

\section{Kibō no ie (House of Hope)}

One of such example is Kibō no ie, house built by a catholic organisation for children, which was established in 1967, few years after the great fire in Higashi Kujō in 1960, when lots of barracks were burnt down. This organisation helped 
parents that they could bring their children into the kindergarten. At first, mostly Koreans were taking children into the day care, but through the years it became much more. It becomes a place where not only children but also adults could get together and talk, and organise events like Madang festival ${ }^{12}-\mathrm{a}$ festival established in 1993 with the purpose for coexistence and cooperation. Project Kibō no ie has also an important role in machizukuri, as they were holding meetings and planing their city area in Higashi Kujō, which is changing very fast-every year we can find a new apartment or community facility around that area.

In 2013 they built a new building, which accommodate also Kyoto City Network Salon for community welfare and multicultural exchange. Every day they have childcare for pre-school children and in afternoon children from primary and secondary school join them and wait for their parents.

In the new building there are also facilities for holding meetings, playing rooms and seminar rooms (Kyoto University is also using them), children or adults can practice instruments or have some courses of English, and women have handicraft and cooking courses. There are also many associations that come to hold meetings in this building and organise other events.

From the first floor on there are apartments which are for renting. As the whole building is financed by Kyoto city government, the rent for the apartment is cheap and it can depend on the income of the person. So besides the Koreans, other groups of people are welcome as well: elderly people, students and thus this became an important establishment, where the multiculturalism is emphasised and accomplished.

Kim Kwangmin says that in 1980 in Higashi Küjo there were no water and sewage yet and there were still many barracks lined up in that area. In that time almost 80 percent of population in that "area number 40" (Kim K. 2013, 2) was

12 Higashi Kujō Madang (東九条マダン) began in 1993 and it was the next turning point in the nursery school (day care) development in Higashi Kujō. One of the executives was Chechu Sōshiku and there was Hanmadan and Korean Youth Association and soon children from Kibo no ie day care centre participated as well. Children from day care performed punmuru (プンムル, Korean traditional art also called noggaku (農学) in Japanese and pungmul-nori (풍물놀이/風物놀이) or nong-ak (농악/農樂) in Korea is performed with music and dance). After they go to primary school and also become youngsters, they return and participate in the Madang festival. Through the years, Kibo no ie became a centre where people could meet in the afternoon and talk, make plans for the future of the neighbourhood or organize festivals. They could practice dance, music (like samur-nori/ サムルノリ, North Korean traditional music with four instruments, which is played in Japan by Koreans). 사물놀이) and other traditional arts. (Kim 2013, 8-10; see also Chin 2013) 
Korean. Whn Kim Kwangmin came to Higashi Kujō from Ikuno (Osaka city) it seemed like the area was forgotten by everyone around it. However, there were some negotiations, and inhabitants were colliding with administration with all their power, but it seemed in that area as if all that they knew was failure.

The catholic centre Kibo no ie was established in 1960, after the great fire in Higashi Kujō when lots of barracks were burnt down and first countermeasures were undertaken. Kim Kwangmin started working in the catholic kindergarten Kibo no ie in 1986 when the kindergarten basic principles were established. Before that it seemed that there were many twists and turns. (Kim K. 2013, 3-4) In 1960, besides barracks, it was also known to be a dangerous place. There were a lot of garbage lying around; many homeless people were wandering around. After the kindergarten was established, it became a place where children of Korean minority (Kankokujin and Chōsenjin) and also children from broken families with singular parents found their place for learning and playing. The sisters and priests in the catholic kindergarten had somehow a different approach to education where each child was treated as an individual, since every child had a different background and personality. Sisters were there until 1977 and then other teachers came to run the kindergarten (Kim K. 2013, 5-6)

In 1982, after some incidents expressing discrimination and after some talks with the school principals from schools in the neighbourhood, the idea of multicultural life appeared. In 1980 there were many foreign residents moving into Higashi Kujō and as the principal of the kindergarten Chechu Sōshiku says, no matter what background you have, everyone has the right to day care and education. (Kim K. 2013, 7-8)

In 2000 the day care centre received support from the city government, but at the same time it also faced a crisis, and preventing from being closed they tried to collect the support with the advertisement through their home page. (Kim K. 2013, 8-9) Since 2002 there were not only Korean volunteers but also people from other countries who volunteered in the centre, from Thailand, Philippines, China, Indonesia, Russia and Finland. (Kim K. 2013, 14) As Kim finally says, multiculturalism in their centre is not just the difference of cultures of foreign countries but also the difference of generations. They have exchanges between people from elderly home as well, as they call it yasuragi kōryu (やすらぎ交流), which means "peaceful exchange". (Kim K. 2013, 14) 
There is another kindergarten with the same name Kibo no ie, which is placed near the river Takasegawa and it was also built for children and as it is written on their website, they want to built $\mathrm{u}$ a place where children can grow up both physically and mentally healthy with the basics in Christian spirit. As it is written on their web page, the centre which is placed southeast of Kyoto Station was built for the children to gather after school and to be taken care for. It is also a place where they can play, where they can learn about issues like healthy living, coexistence with the environment, education, aging and multi-ethnic. They are deeply involved with the local community, cherishing the culture of Korea. There are exchange programs with the elderly in the region, and they keep an eye on environmental issues and poverty in the world. (Kibonoie Hoikuen) There are events for children like hanami, evacuation training, various tournaments and children's Christmas meetings and handicraft classes, cooking classes, theater playing, school club events, welcome parties, excursions, parent-child camps, birthday parties, events for teenagers, etc.

They also have ontents for parents, like consultations, parenting courses, mother clubs, exchanges with other families and local residents, interaction activities with the elderly and people with disabilities. (Kibonoie Hoikuen)

\section{Concluding Remarks}

Because community initiative is not the same as legislation procedure, but rather an alternative comprehensive approach to city-building, it incorporated the thinking of the superstructure of a municipality and also of its soul. That is to say, the machizukuri concept integrated the people of the community into its making. It was not, however, simply a matter of increased public participation. The movement towards machizukuri was viewed as a step towards re-vitalization of civil society in Japan, a form of decentralisation that works towards the reconstruction of the notion of local community.

The experience of segregation and discrimination and the history of local isolation have given groups of people to live their lives in self-governing communities in search for happy dwelling. With the communities' own unique background and historical background these localities are also capable of functioning as models of self-governance and authority. They enjoy the position of equality with their surrounding neighbourhoods when it comes to community initiative. Especially with the community house like Kibō no ie, they manage to 
bring together many different people of different nationalities and age groups and build a centre where people can meet and talk about their past and future living in Kyoto city.

These experiences of one marginalised groupd also provide many benefits for other marginalised communities, such as zaninichi Koreans and the handicapped, who were formerly forced to live together but are today trying in various ways to get the best of such multicultural environment. It is possible to conclude that negative consequences of marginality served as a starting point for innovation and potentials, marginality can even provide an extra edge to start development and serve to connect people.

\section{References}

Boyle, Tim. "A Brief History of Buraku Discrimination in Japan.” Osaka: Buraku Liberation Center, United Church of Christ in Japan. Accessed November 30, 2013. http://www.konkyo.org/burakukaiho/news/burakuhistory.pdf\#sthash.MF0wcpnp.dpuf.

Buraku Liberation League. "Buraku mondai to wa? 部落問題とは? (What is the Buraku Problem?)" Accessed November 15, 2013. http://www.bll.gr.jp/kaisetu.html.

Chapman, David. 2008. Zainichi Korean Identity and Ethnicity. London and New York: Routledge.

Chin Taiichi 陳太一. 2013. "Kyōsei, Kyōdō no matsuri Higashi Kujō Madan. Nihon-seki chōsenjin toshite no kakawari 共生・協働のまつり京都マダン一日本籍朝鮮人と しての関わり (Festival of Coexistence and Cooperation - Higashi Kujō Madan.

Connections of Japanese Koreans).” In Tabunka shakai wo ikiru 多文化社会を生き る, edited by Kyōto shi chiiki, 21-38. Kyōto: Kyōto shi chiiki, Tabunka kōryū netto waaku saron.

Fukuoka, Yasunari. 2000. Life of Young Koreans in Japan. Translated by Tom Gill. Melbourne: Trans Pacific Press.

Fukuoka, Yasunari, and Tsujiyama, Yukiko 福岡安則，辻山ゆき子. 1991. Dōka to ika no hazama de - "Zainichi” wakamono sedai no aidenteitei kattō 同化と異化のはざ まで 一在日若者のアイデンティティー葛藤 (Assimilation versus Dissimilation: Identity Conflict among Young Koreans in Japan.) Tōkyō: Shinkansha.

Gurung, Ghana S., and Kollmair, Michael. 2005. "Marginality: Concepts and their Limitations." IP6 Working Paper No. 4. Zurich: University of Zurich, NCCR NorthSouth.

Hicks, George L. 1997. Japan's Hidden Apartheid: the Korean Minority and the Japanese. Aldershot: Ashgate.

Inadsugi Tadashi 柳井正 2002. “Zainichi Kankoku, Chōsenjin no shakai idō 在日韓国、 朝鮮人の社会移動 (Social Mobility of Resident Koreans and North Koreans).” In 
Minzoku kankei ni okeru ketsugō to bunri 民族関係における結合と分離, edited by Tomio Tani 谷 富夫, 559-95. Tōkyō: Minerva.

“Kibonoie Hoikuen 希望の家保育園.” Accessed August 15, 2014. http://www.kyotokibounoie-hoikuen.ed.jp/.

Kim Donfun, ed. 金東勲. 2002. “Kokusai jinken-hō to zainichi gaikokujin no jinken 国際 人権法と在日外国人の人権 (International Human Rights Law and Human Rights of Foreigner Residents)." In Dōwa mondai kenkyū shiryō. Takasegawa wo aruku II Higashi kujo to zainichi Koriajin 同和問題研究材料・高瀬川を歩く II 一東九条と 在日コリア人, 6-32. Kyoto: Ishida taisei sha.

Kim Kwangmin 金光敏. 2013. “Tabunka kyōsei kyōiku - Kibō no ie katolikku kyōikuen no torikumi 多文化共生教育一希望の家カトリック教育園の取り組み (Multicultural Education: Efforts of House of Hope Kindergarden)." In Tabunka shakai wo ikiru 多文化社会を生きる, edited by 京都市地域 Kyōto shi chiiki, 2-20. Kyōto: Kyōto si chiiki, Tabunka kōryū netto wa-ku saron.

Kyoto City. 2010. "Outline of the Master Plan of Kyoto City." Asscessed January, 15. 2014. http://www.city.kyoto.jp/koho/eng/plan/img/english.pdf.

Kyoto's Buraku Liberation League 部落解放同盟 (Buraku Kaihō Dōmei) “Kyōtoshi Buraku no jitsujō o haaku subeki wa darena no ka 京都市部落の実情を把握すべき わ誰のか (Who Should Understand the Actual Situation in the Buraku in the Kyoto City?)." Accessed November 15, 2013.

http://www.city.kyoto.lg.jp/bunshi/cmsfiles/contents/0000044/44842/2siryoub.pdf.

Maekawa Osamu 前川修. 1974. “Higashi shichi-jō ni okeru barakku no taisaku to Shinkansen fusetsu 東七条におけるバラックの対策と新幹線敷設 (Countermeasures to Barracs and Construction of Shinkansen in Higashi shichi jo)” Buraku Mondai Kenkyū 部落問題研究 38: 39-61. Accessed October 30, 2013. http://blhrri.org/info/book_guide/kiyou/ronbun/kiyou_0141-02.pdf .

Matsunaga, Masaki, and Torigoe, Chie. 2007. "Looking at the Japan-Residing Korean Identities through the Eyes of the "Outsiders Within": Application and Extension of Co-cultural Theory." Western Journal of Communication 72(4): 349-73.

McCormack, Noah Y. 2013. Japan's Outcaste Abolition: The Struggle for National Inclusion and the Making of the Modern State. New York. Routledge.

Minami ku. Asscessed October 10, 2013. http://www.city.kyoto.lg.jp/minami/index.html.

Ministry of Justice 2010. Accessed October 10, 2013. http://www.moj.go.jp/nyuukokukanri/kouhou/nyuukantourokusya toukei110603.htm.

Mist, Sigurbjörnsdóttir Kristín. 2012. "Japan’s Forsaken People. Burakumin in Contemporary Society." Unpublished BA thesis. Accessed October 10, 2013. http://skemman.is/stream/get/1946/10656/26501/1/Krist\%C3\%ADn_Mist.pdf.

Mizuuchi, Toshio. 2002. "The Historical Transformation of Poverty, Discrimination, and Urban Policy in Japanese City: The Case of Osaka." Accessed November 12, 2013. http://www.lit.osaka-cu.ac.jp/geo/pdf/frombelow/0308_frombelow_mizuuchi.pdf. 
Neary, Ian J. 2009 (1997). "Burakumin in Contemporary Japan.” In Japan's Minorities. The Illusion of Homogeneity, edited by Michael Weiner, 59-83. New York: Routledge.

Okano, Kaori. 1997. "Third-Generation Koreans' Entry into the Workforce in Japan." Anthropology \& Education Quarterly 28(4): 524-49.

Ruyle, Eugene E. 1979. "Conflicting Japanese Interpretations of the Outcaste Problem (Buraku mondai)." American Ethnologist 6(1), Feb.: 55-72. Accessed April 4, 2014. http://www.jstor.org/stable/643384.

Ryang, Sonia, ed. 2005 (2000). "Introduction: Resident Koreans in Japan.” In Koreans in Japan. Critical Voices from the Margin, 1-12. London and New York: Routledge Curzon.

Shimogyō-ku. Accessed January 15, 2014. http://www.city.kyoto.lg.jp/shimogyo/.

Sorensen, André. 2002. The Making of Urban Japan Cities and Planning from Edo to the Twenty-first Century. London and New York: Routledge.

Sorensen, André, and Funck, Carolin, eds. 2007. "Living Cities in Japan.” In Living Cities in Japan: Citizens' Movement, machizukuri and Local Environments, 1-36. London and New York: Nissan Institute and Routledge.

Tai, Eika. 2006. “Korean Japanese.” Critical Asian Studies 36(3): 355-82. Accessed October 25, 2012. http://dx.doi.org/10.1080/1467271042000241586.

Visočnik, Nataša. 2013. "Self- and Other- Representations of the Korean Minority in Japan.” Dve Domovini/Two Homelands 37: 113-22.

—. 2014. "Living on the Edge: Buraku in Kyoto, Japan." Anthropological Notebooks 20(2): 127-43.

Weiner, Michael, ed. 2009 (1997). “'Self' and 'Other' in Imperial Japan.” In Japan's Minorities. The Illusion of Homogeneity, 1-20. New York: Routledge.

Yamamoto Tetsuji 山本哲司. 2009. “Hisabetsu buraku ni okeru 'Hisabetsu hyōshō' to machizukuri no kadai. Seikatsushi no kikitori kara 被差別部落におけるく被差別の 表象〉とまちづくりの課題一生活史の聞き取りから ('Discriminated Representations' and the Challenges of Community Building in Discriminated Buraku).”Ryukoku Kiyō 龍谷紀要 30(2): 37-54. Accessed December 15, 2013. http://repo.lib.ryukoku.ac.jp/jspui/bitstream/10519/741/1/r-ky_030_02_005.pdf. 